\title{
Pengaruh Rasio Bunga Dengan Pelarut Terhadap Rendemen dan Mutu Minyak Melati (Jasminum Sambac) Menggunakan Metode Ekstraksi Pelarut Menguap (Solvent Extraction) (The Effect of Flower-Solvent Ratio to The Yield and Quality of Jasmine Essential Oil (Jasminum sambac)Using Solvent Extraction Method)
}

\author{
Nur Oktavia Benedicta ${ }^{1)}$, Sudaryanto Zain ${ }^{2)}$, Sarifah Nurjanah ${ }^{2)}$, Asri Widyasanti ${ }^{2)}$, Selly Harnesa Putri ${ }^{2)}$ \\ ${ }^{1)}$ Alumnus Departemen Teknik Pertanian dan Biosistem, Fakultas Teknologi Industri Pertanian \\ ${ }^{2)}$ Staf Pengajar Fakultas Teknologi Industri Pertanian, Universitas Padjadjaran \\ Jl. Raya Bandung Sumedang KM 21, Jatinangor Bandung 40600 \\ Email :benedictanuroktavia@yahoo.com
}

\begin{abstract}
ABSTRAK
Salah satu metode yang dapat digunakan untuk mengekstraksi minyak melati adalah metode ekstraksi pelarut menguap. Metode ekstraksi pelarut menguap memiliki kelebihan yaitu mudah dan cepat dilakukan namun rendemen yang dihasilkan masih rendah. Berdasarkan beberapa hasil penelitian yang telah dilakukan, peningkatan rasio bunga dengan pelarut dapat meningkatkan rendemen minyak melati yang dihasilkan. Tujuan penelitian ini adalah untuk mempelajari pengaruh rasio bunga dengan pelarut terhadap rendemen dan mutu minyak melati menggunakan metode ekstraksi pelarut menguap. Metode penelitian yang digunakan adalah eksperimen laboratorium dengan analisis deskriptif. Rasio bunga melati dengan pelarut $n$-heksan yang digunakan adalah 1:2, 1:3, dan 1:4, masing-masing diulang sebanyak 2 kali. Hasil penelitian menunjukkan nilai rendemen berkisar antara 0,15-0,27\%. Minyak melati yang dihasilkan berwarna kuning dengan nilai bobot jenis $0,8379-0,8805$, indeks bias $1,369-1,396$, bilangan asam 4,4173 $-8,2800 \mathrm{mg} \mathrm{KOH} / \mathrm{g}$, kelarutan dalam alkohol 1:1, dan kadar sisa pelarut 26,00 -40,00\%.
\end{abstract}

Kata kunci : rasio, bunga melati, n-heksan, pelarut menguap.

\begin{abstract}
One of the methods that can be used to extract jasmine oil is solvent extraction method. The advantages of solvent extraction method are easy and fast to do, but the yield is low. Based on research that has been done, the increase of flower-solvent ratio could increase the yield of jasmine oil produced. This research aimed to find out the effect of flower-solvent ratio to the yield and quality of jasmine oil using solvent extraction method. This research used laboratory experiment method with descriptive analysis. The flowersolvent ratio that used were 1:2, 1:3, and 1:4, repeated 2 times. The results showed the jasmine oil's yield value were $0.15 \%-0.27 \%$. The color of jasmine oil were yellow with the value of specific gravity $0.8379-$ 0.8805 , refractive index $1.369-1.396$, acid number $4.4173-8.2800 \mathrm{mg} \mathrm{KOH} / \mathrm{g}$, solubility in alcohol 1:1, and residual solvent content $26.00 \%-40.00 \%$.
\end{abstract}

Keywords : ratio, jasmine flower, $n$-hexan, solvent extraction.

Diterima : 15 September 2016; Disetujui : 28 Oktober 2016

44 Pengaruh Rasio Bunga Dengan Pelarut Terhadap Rendemen dan Mutu Minyak Melati (Jasminum Sambac) Menggunakan Metode Ekstraksi Pelarut Menguap (Solvent Extraction) 


\section{PENDAHULUAN}

Melati merupakan salah satu tanaman komoditas bernilai tinggi untuk menghasilkan minyak atsiri. Minyak atsiri melati dapat dimanfaatkan sebagai bahan baku dalam berbagai industri, misalnya pada industri kosmetik, sabun, parfum, farmasi dan aroma terapi. Salah satu metode yang dapat digunakan untuk mengekstrak minyak melati adalah dengan metode pelarut menguap. Teknik ekstraksi pelarut menguap memanfaatkan pelarut mudah menguap untuk memisahkan minyak dari jaringan tumbuhan. Ekstraksi minyak melati dengan menggunakan pelarut menguap ini termasuk jenis ekstraksi padat-cair (leaching). Pemindahan komponen minyak melati dari dalam bunga melati ke pelarut pada ekstraksi padat-cair berlangsung secara difusi.

Salah satu faktor yang mempengaruhi ekstraksi adalah jumlah pelarut yang digunakan. Menurut Prabawati (2002), penggunaan lebih banyak pelarut dapat meningkatkan minyak melati yang diperoleh. Pernyataan tersebut dibuktikan oleh hasil penelitiannya dan hasil penelitian Rosmayati (1999) yang menunjukkan bahwa rendemen minyak melati lebih tinggi dengan menggunakan rasio bunga dan pelarut sebesar 1:2 daripada 1:1,5. Begitupun halnya pada penelitian ekstraksi minyak mawar yang dilakukan oleh Amiarsi (2006), rasio bunga dengan pelarut sebesar 1:3 menghasilkan rendemen tertinggi dibandingkan dengan rasio 1:1 dan 1:2. Penelitian ini dilakukan untuk mengetahui bagaimana pengaruh dari rasio bunga dengan pelarut terhadap rendemen dan mutu minyak melati yang dihasilkan.

\section{METODOLOGI PENELITIAN}

Penelitian ini dilakukan pada bulan Juni hingga September 2016 bertempat di Desa Kaliprau Kecamatan Ulujami Kabupaten Pemalang Jawa Tengah, Laboratorium Pasca Panen dan Teknologi Proses, dan Laboratorium Keteknikan Pengolahan Pangan Fakultas Teknologi Industri Pertanian Universitas Padjadjaran. Bahan penelitian yang digunakan adalah bunga melati putih (Jasminum sambac) dengan tingkat kemekaran bunga M-1 (kuncup siap mekar) yang dipanen pada pagi hari pukul $06.00 \mathrm{WIB}$, pelarut nheksan, etanol 96\%, aquades, $\mathrm{KOH} 0,1 \mathrm{~N}$, dan Fenolftalein (pp). Metode penelitian yang digunakan adalah eksperimen laboratorium dengan analisis deskriptif dengan menggunakan 3 perlakuan yaitu rasio massa bunga dengan massa pelarut n-heksan 1:2, 1:3 dan 1:4 (b/b). Masingmasing perlakuan dilakukan 2 kali ulangan. Berikut merupakan diagram alir proses ekstraksi dengan metode pelarut menguap.

Cara kerja ekstraksi dengan pelarut menguap ini mengacu pada prosedur Rosmayati (1999) yaitu dengan cara merendam bunga melati dalam pelarut $n$-heksan selama 12 jam pada suhu ruang dengan massa bunga dan pelarut disesuaikan dengan perlakuan yang digunakan. Pelarut akan berdifusi ke dalam bunga melati dan melarutkan minyak bunga melati beserta lilin dan albumin serta zat warna. Larutan tersebut selanjutnya dievaporasi dalam keadaan vakum pada suhu $35{ }^{\circ} \mathrm{C}$ untuk dipisahkan dari pelarut $\mathrm{n}$ heksan. Setelah $n$-heksan dievaporasi, lilin dan zat semi padat yang dikenal dengan concrete akan tertinggal. Concrete merupakan cairan kental berwarna kuning yang memiliki aroma wangi melati, mengandung minyak atsiri melati dan zat lilin yang ikut terekstrak namun zat lilin tersebut tidak dapat dipisahkan dengan evaporasi. Concrete dilarutkan dengan etanol sehingga senyawa aromatik dapat terekstrak dan menyisakan zat yang tidak larut dalam etanol seperti zat lilin. Lilin dipisahkan dari larutan dengan cara penyaringan. Kemudian etanol dalam larutan dievaporasi secara vakum pada suhu $40{ }^{\circ} \mathrm{C}$ hingga menyisakan absolute. Diagram alir proses ekstraksi tersaji pada Gambar 1.

Variabel yang diamati pada penelitian ini meliputi suhu dan kelembaban relatif ruangan, waktu evaporasi vakum, suhu minyak pada pengujian bobot jenis dan indeks bias. Sedangkan parameter yang dihitung terdiri dari rendemen parsial dan rendemen total. 


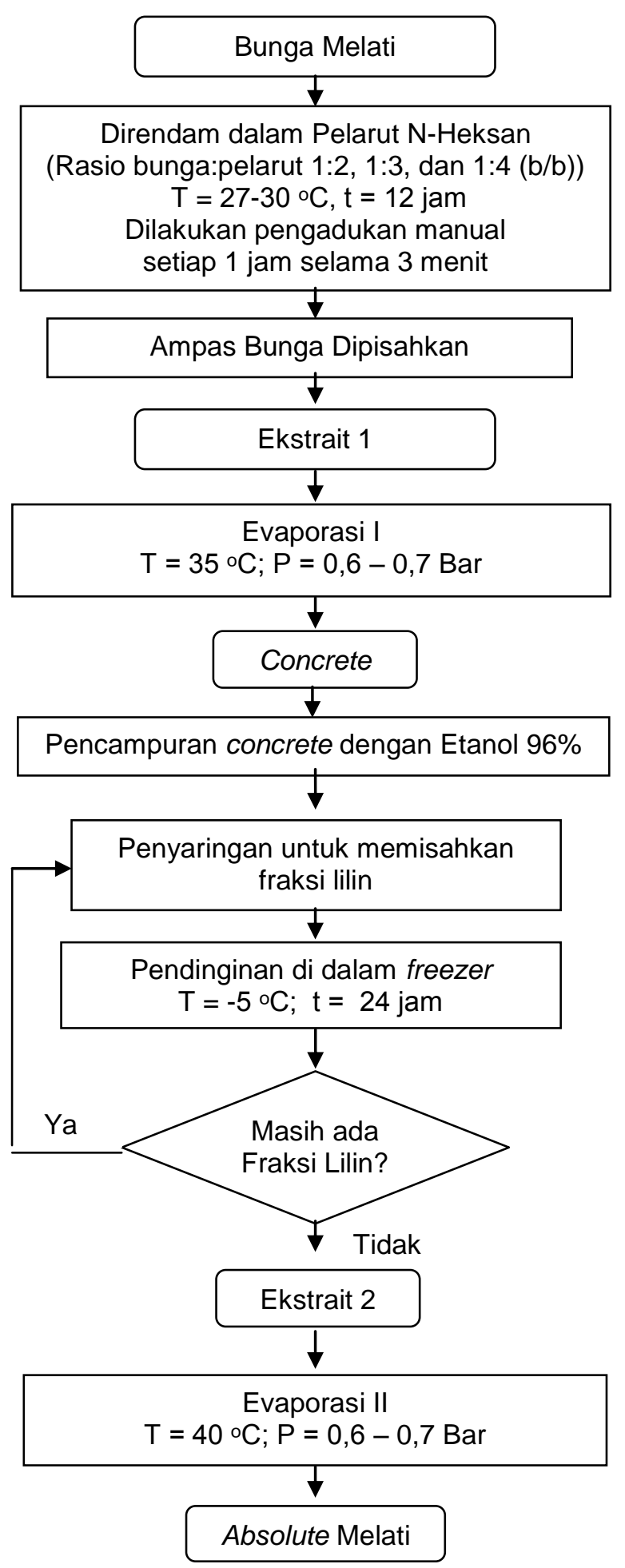

Gambar 1. Diagram Alir Proses Ekstraksi

Adapun parameter mutu minyak melati yang dianalisis berupa uji fisiko kimia minyak melati yang terdiri dari warna, aroma, bobot jenis, indeks bias, bilangan asam, kelarutan dalam alkohol, serta kadar sisa pelarut. Pada penelitian ini juga dilakukan analisis komponen minyak melati menggunakan instrumen GCMS pada satu sampel terbaik minyak melati.

\section{HASIL DAN PEMBAHASAN}

\section{Pengaruh Rasio Bunga dengan Pelarut Terhadap Rendemen Minyak Melati}

Rendemen total adalah persentase perbandingan massa absolute dengan massa bunga melati. Rendemen total minyak melati hasil penelitian mengalami peningkatan seiring dengan peningkatan jumlah pelarut yang digunakan. Gambar 2 menunjukkan peningkatan nilai rendemen minyak melati

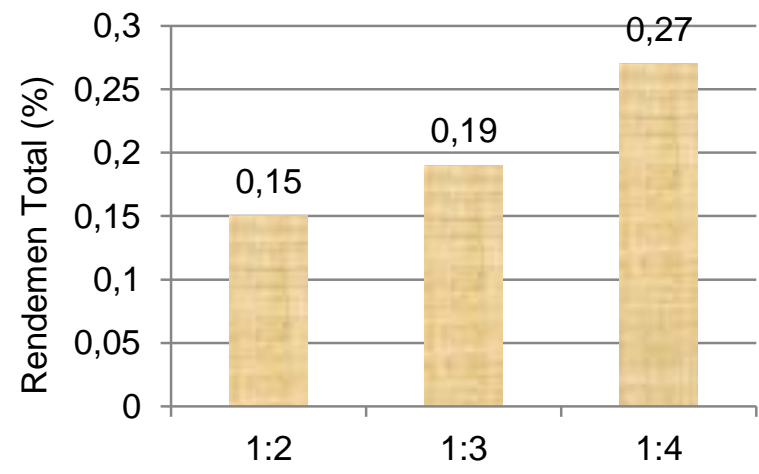

Perbandingan Imbangan Bunga dengan Pelarut $(b / b)$

Gambar 2. Grafik Peningkatan Rendemen Minyak Melati

Hasil penelitian ini sesuai dengan pernyataan yang dikemukakan oleh Prabawati (2002), bahwa semakin banyak pelarut yang digunakan maka semakin banyak minyak yang terekstrak. Hal ini disebabkan semakin besarnya rasio pelarut terhadap bunga maka perbedaan konsentrasi antara pelarut dengan komponen yang terkandung di dalam bunga semakin tinggi. Dengan demikian rendemen ekstraksi akan semakin meningkat. Selain itu peningkatan nilai rendemen diduga disebabkan oleh meningkatnya luas kontak bunga melati dengan pelarut. Jayanudin (2014) menambahkan bahwa banyaknya pelarut mempengaruhi luas kontak padatan dengan pelarut, semakin banyak pelarut maka luas kontak akan semakin besar. Meratanya distribusi pelarut

46 Pengaruh Rasio Bunga Dengan Pelarut Terhadap Rendemen dan Mutu Minyak Melati (Jasminum Sambac) Menggunakan Metode Ekstraksi Pelarut Menguap (Solvent Extraction) 
ke padatan akan memperbesar rendemen minyak atsiri yang dihasilkan. Banyaknya pelarut akan mengurangi kejenuhan pelarut, sehingga komponen minyak dalam bunga akan terekstrak secara sempurna.

Pada penelitian ini perlakuan yang menghasilkan nilai rendemen tertinggi adalah perlakuan rasio bunga dengan pelarut 1:4. Namun perlakuan 1:4 tersebut belum dapat dikatakan perlakuan yang optimal karena belum diketahui bagaimana nilai rendemen minyak melati yang diperoleh apabila rasio bunga dengan pelarut lebih dari 1:4. Rasio 1:4 dapat dikatakan optimal apabila diketahui rasio di atas 1:4 menghasilkan nilai rendemen yang lebih rendah daripada rendemen dengan rasio 1:4.

\section{Pengaruh Rasio Bunga dengan Pelarut Terhadap Mutu Minyak Melati}

\section{1) Aroma}

Pengujian aroma dilakukan dengan uji organoleptik berdasarkan tingkat kesukaan panelis terhadap aroma minyak melati. Uji tingkat kesukaan dilakukan dengan uji rangking dengan hasil pengujian tertera pada Tabel 1.

Tabel 1. Penilaian Aroma Berdasarkan Rangking

\begin{tabular}{ccc}
\hline Perlakuan & Rangking & Keterangan \\
\hline $1: 2$ & 1 & Sangat Suka \\
\hline $1: 3$ & 2 & Suka \\
\hline $1: 4$ & 3 & Kurang Suka \\
\hline
\end{tabular}

Dari Tabel 1 diatas, dapat diketahui bahwa sampel yang paling disukai sampai yang kurang disukai oleh panelis secara berturut-turut adalah sampel minyak melati perlakuan 1:2, 1:3, dan 1:4. Dari hasil uji rangking tersebut terlihat bahwa semakin banyak pelarut yang digunakan maka panelis semakin kurang menyukai aroma minyak melati yang dihasilkan.

\section{2) Warna}

Pengujian warna dilakukan dengan menggunakan alat kromameter dengan hasil kuantitatif tertera pada Tabel 2.
Tabel 2. Nilai Warna Minyak Melati

\begin{tabular}{ccccccc}
\hline \multirow{2}{*}{ Perlakuan } & \multicolumn{7}{c}{ Parameter Warna } & \multirow{2}{*}{ Warna } \\
\cline { 2 - 6 } & L* & a* & b* & C & h & \\
\hline $1: 2$ & 89,41 & $-3,43$ & 56,26 & 56,37 & 93,63 & Kuning \\
$1: 3$ & 93,22 & $-5,30$ & 61,39 & 61,62 & 94,94 & Kuning \\
$1: 4$ & 96,85 & $-6,30$ & 65,09 & 65,43 & 96,19 & Kuning \\
\hline
\end{tabular}

Menurut Ketaren (1985), warna minyak melati adalah kuning kecoklatan. Minyak melati hasil penelitian ini berwarna kuning dengan tingkat kecerahan yang tinggi dimana nilai $L^{*}$ berkisar antara 89,41 sampai 96,85 . Notasi L* menyatakan kecerahan, bernilai 0 (hitam) sampai 100 (putih). Notasi a* menyatakan campuran warna merah hijau dimana a* negatif berwarna merah dan a* positif berwarna hijau. Pada penelitian ini minyak melati yang dihasilkan memiliki unsur warna merah karena a* bernilai negatif. Namun warna merah tersebut tidak dominan karena nilai a* hanya berkisar antara $-3,43$ sampai $-6,30$. Notasi $b^{*}$ menyatakan campuran warna biru kuning dimana $b^{*}$ negatif berwarna biru dan $b^{*}$ positif berwarna kuning. Nilai C (Chroma) menunjukkan tingkat ketegasan dan keburaman suatu warna, semakin besar nilai $\mathrm{C}$ maka semakin tegas warna yang diukur.

\section{3) Bobot Jenis}

Perlakuan imbangan bunga dengan pelarut berpengaruh terhadap nilai bobot jenis. Semakin tinggi rasio bunga dengan pelarut artinya semakin banyak jumlah pelarut yang digunakan, semakin tinggi pula nilai bobot jenis minyak melati yang dihasilkan. Nilai bobot jenis hasil penelitian ini tertera pada Tabel 3.

Tabel 3. Nilai bobot Jenis Minyak Melati

\begin{tabular}{cc}
\hline Perlakuan & Bobot Jenis \\
\hline $1: 2$ & 0,8379 \\
\hline $1: 3$ & 0,8485 \\
\hline $1: 4$ & 0,8805 \\
\hline
\end{tabular}

Peningkatan nilai bobot jenis diduga karena semakin banyak pelarut yang digunakan maka semakin banyak komponen yang terekstraksi dari dalam bunga. Bobot jenis sering dihubungkan dengan fraksi berat komponen-komponen yang 
terkandung di dalamnya. Menurut Guenther (1987), semakin besar fraksi berat yang terkandung dalam minyak, maka semakin besar pula nilai bobot jenisnya. Diduga pada minyak hasil ekstraksi ini terutama pada perlakuan 1:4 mengandung komponen dengan rantai karbon panjang dan berat molekul yang tinggi sehingga nilai bobot jenis menjadi tinggi.

\section{4) Indeks Bias}

Sama halnya dengan bobot jenis, indeks bias menunjukkan banyaknya komponen yang terkandung di dalam zat. Semakin tinggi nilai indeks bias suatu zat diduga semakin banyak komponen yang terkandung di dalam zat tersebut karena zat dengan komponen yang banyak akan sulit untuk membiaskan cahaya. Menurut Rubiarto (1993), semakin panjang rantai karbon menyebabkan tingkat kerapatan minyak akan semakin tinggi, sehingga lebih sukar membiaskan cahaya yang datang, dan menyebabkan nilai indeks bias menjadi lebih tinggi.

Pada hasil penelitian ini semakin meningkatkan rasio bunga dengan pelarut, nilai indeks bias semakin meningkat. Hal ini diduga karena semakin banyak pelarut yang digunakan maka semakin banyak pula komponen yang terekstrak sehingga nilai indeks bias semakin tinggi. Komponen yang terekstrak tersebut diduga merupakan komponen dengan rantai karbon panjang yang menyebabkan tingkat kerapatan minyak semakin tinggi sehingga semakin sulit membiaskan cahaya yang datang. Nilai indeks bias hasil penelitian ini tersaji pada Tabel 4 .

Tabel 4. Nilai Indeks Bias Minyak Melati

\begin{tabular}{cc}
\hline Perlakuan & Indeks Bias \\
\hline $1: 2$ & 1,369 \\
\hline $1: 3$ & 1,376 \\
\hline $1: 4$ & 1,396 \\
\hline
\end{tabular}

Menurut Rusli (1985), indeks bias memiliki korelasi positif dengan bobot jenis. Korelasi positif artinya keterkaitan antara variabel satu dengan variabel lain berjalan beriringan. Korelasi antara bobot jenis dengan indeks bias dapat dilihat pada Gambar 3 berikut.

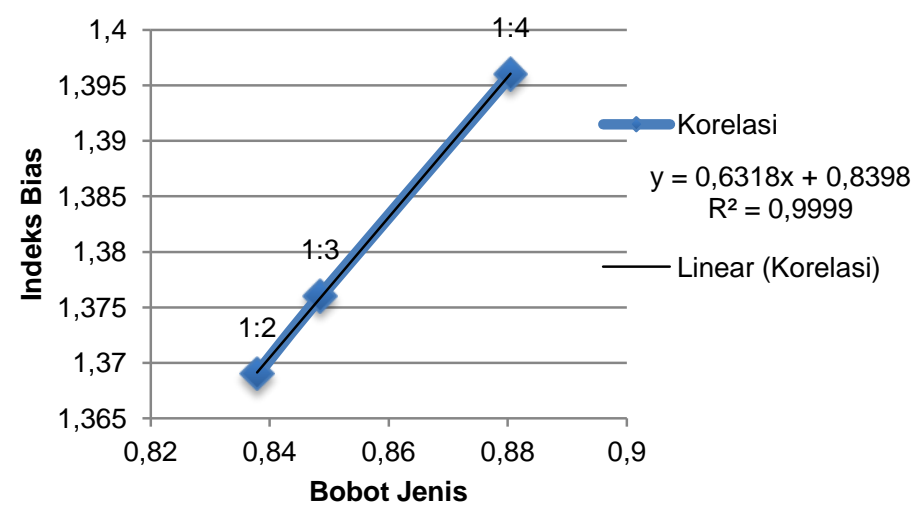

Gambar 3. Grafik Korelasi Indeks Bias Terhadap Bobot Jenis Minyak Melati

Kuat lemahnya keterkaitan tersebut dinyatakan dalam nilai $\mathrm{R}^{2}$ atau yang disebut dengan koefisien determinasi yang bernilai 0 sampai 1, semakin mendekati nilai 1 maka keeratan kedua variabel semakin meningkat. Pada Gambar 4 diatas, nilai koefisien determinasi $\left(R^{2}\right)$ adalah 0,999 artinya keterkaitan antara nilai bobot jenis dengan nilai indeks bias sangat kuat yaitu sebesar 0,999 atau $99,90 \%$.

\section{5) Bilangan Asam}

Pada hasil penelitian ini nilai bilangan asam semakin meningkat seiring peningkatan jumlah pelarut yang digunakan. Nilai bilangan asam minyak melati hasil penelitian ini tertera pada Tabel 5.

Tabel 5. Nilai Bilangan Asam Minyak Melati

\begin{tabular}{cc}
\hline Perlakuan & $\begin{array}{c}\text { Rata-rata Bilangan Asam } \\
\text { ( } \mathbf{m g ~ K O H} / \mathbf{g} \text { ) }\end{array}$ \\
\hline $1: 2$ & 4,4173 \\
\hline $1: 3$ & 7,2495 \\
\hline $1: 4$ & 8,2800 \\
\hline
\end{tabular}

Rasio bunga dengan pelarut berpengaruh terhadap bilangan asam minyak melati hasil ekstraksi. Nilai bilangan asam semakin meningkat seiring dengan meningkatnya rasio bunga dengan pelarut. Semakin tinggi bilangan asam mengindikasikan bahwa semakin banyak asam bebas yang terkandung di dalam minyak melati. Asam bebas tersebut diduga berasal dari fraksi lilin yang ikut terekstrak bersama dengan minyak

48 Pengaruh Rasio Bunga Dengan Pelarut Terhadap Rendemen dan Mutu Minyak Melati (Jasminum Sambac) Menggunakan Metode Ekstraksi Pelarut Menguap (Solvent Extraction) 
melati. Semakin banyak pelarut yang digunakan semakin banyak pula komponen yang terekstrak. Komponen yang terekstrak ini tidak hanya minyak melati tetapi juga komponen lain termasuk fraksi lilin yang tidak dapat dipisahkan dari minyak melati. Lubis (1999) mengatakan bahwa asam lemak bebas yang telah terlarut dalam etanol akan tetap tertinggal pada absolute melati karena asam lemak bebas tidak dapat teruapkan bersama dengan etanol.

\section{6) Kelarutan dalam Alkohol}

Pengujian kelarutan dalam alkohol dilakukan untuk mengetahui jumlah alkohol yang dibutuhkan untuk melarutkan sejumlah minyak melati. Pada penelitian ini seluruh sampel minyak melati memiliki nilai kelarutan dalam alkohol sebesar 1:1. Menurut Guenther (1987), minyak atsiri yang kaya akan komponen teroksigenasi lebih mudah larut dalam alkohol daripada komponen yang kaya akan terpen. Komponen teroksigenasi merupakan komponen yang penting dalam minyak atsiri karena umumnya aroma yang lebih wangi dan mempunyai kelarutan yang tinggi dalam alkohol encer, serta lebih tahan dan stabil terhadap proses oksidasi dan resinifikasi.

\section{7) Kadar Sisa Pelarut}

Pada hasil penelitian, banyaknya pelarut yang digunakan berpengaruh terhadap nilai kadar sisa pelarut. Semakin besar rasio bunga dengan pelarut, nilai kadar sisa pelarut semakin tinggi. Semakin tinggi nilai kadar sisa pelarut dalam minyak melati maka mutu minyak melati semakin rendah. Tabel 6 merupakan nilai kadar sisa pelarut minyak melati hasil ekstraksi.

Tabel 6. Kadar Sisa Pelarut Minyak Melati

\begin{tabular}{cc}
\hline Perlakuan & $\begin{array}{c}\text { Kadar Sisa Pelarut } \\
\text { (\%) }\end{array}$ \\
\hline $1: 2$ & 26,00 \\
\hline $1: 3$ & 32,00 \\
\hline $1: 4$ & 40,00 \\
\hline
\end{tabular}

Guenther (1987) menyatakan bahwa minyak atsiri merupakan campuran yang kompleks, sehingga sulit untuk menentukan dengan pasti sisa pelarut yang tidak menguap. Hal ini dikarenakan lilin dan bahan tidak menguap bertitik didih tinggi cenderung mengikat komponen yang bertitik didih rendah. Oleh karena itu semakin banyak pelarut yang digunakan maka kadar sisa pelarutnya juga semakin tinggi.

\section{Analisis Komponen Minyak Melati}

Berdasarkan analisis GCMS, minyak melati hasil penelitian ini mengandung 7 komponen utama dengan persentase komponen dapat dilihat pada Tabel 7.

Tabel 7. Komponen Utama Minyak Melati

\begin{tabular}{cccc}
\hline Golongan & $\begin{array}{c}\text { Nama } \\
\text { Komponen }\end{array}$ & $\begin{array}{c}\text { Rumus } \\
\text { Molekul }\end{array}$ & $\begin{array}{c}\text { Persentase } \\
\text { (\%) }\end{array}$ \\
\hline Hidrokarbon & Farnesene & $\mathrm{C}_{15} \mathrm{H}_{24}$ & 10,54 \\
\cline { 2 - 4 } & Hexacosane & $\mathrm{C}_{26} \mathrm{H}_{54}$ & 5,37 \\
\hline \multirow{3}{*}{$\begin{array}{c}\text { Eicosanol } \\
\text { Hidrokarbon }\end{array}$} & $\mathrm{C}_{20} \mathrm{H}_{42} \mathrm{O}$ & 19,04 \\
\cline { 2 - 4 } $\begin{array}{c}\text { Benzil } \\
\text { Asetat }\end{array}$ & $\mathrm{C}_{9} \mathrm{H}_{10} \mathrm{O}_{2}$ & 16,57 \\
\cline { 2 - 4 } & Linalol & $\mathrm{C}_{10} \mathrm{H}_{18} \mathrm{O}$ & 12,94 \\
\cline { 2 - 4 } & $\begin{array}{c}\text { Hexenil } \\
\text { Benzoat }\end{array}$ & $\mathrm{C}_{13} \mathrm{H}_{16} \mathrm{O}_{2}$ & 8,55 \\
\cline { 2 - 4 } & $\begin{array}{c}\text { Etil } \\
\text { Linoleolate }\end{array}$ & $\mathrm{C}_{20} \mathrm{H}_{36} \mathrm{O}_{2}$ & 4,53 \\
\hline
\end{tabular}

Komponen hidrokarbon teroksigenasi pada minyak melati hasil penelitian ini lebih banyak dibandingkan dengan komponen hidrokarbon. Hal ini yang menyebabkan minyak melati hasil penelitian ini memiliki aroma yang harum karena menurut Guenther (1987), golongan hidrokarbon teroksigenasi merupakan senyawa yang umumnya beraroma lebih wangi. Ketaren (1985) menambahkan bahwa komponen utama persenyawaan minyak melati adalah benzil asetat dan linalool sehingga pada penelitian ini komponen yang menyebabkan aroma wangi tersebut diduga adalah komponen linalool dan komponen benzil asetat dengan masing-masing persentase sebesar $12,94 \%$ dan $16,57 \%$.

\section{KESIMPULAN DAN SARAN}

\section{Kesimpulan}

Berdasarkan penelitian yang telah dilakukan, dapat disimpulkan : 
1. Rasio bunga dengan pelarut berpengaruh terhadap rendemen minyak melati dengan nilai rendemen tertinggi yaitu sebesar $0,27 \%$ pada perlakuan 1:4, 0,18\% pada perlakuan 1:3, dan perlakuan 1:2 menghasilkan nilai rendemen terendah yaitu $0,15 \%$.

2. Rasio bunga dengan pelarut berpengaruh terhadap mutu minyak melati. Berdasarkan mutu aroma, bilangan asam, dan kadar sisa pelarut yang terbaik adalah perlakuan rasio 1:2 dengan aroma wangi, nilai bilangan asam 4,4173 $\mathrm{mgKOH} / \mathrm{g}$, dan nilai kadar sisa pelarut $28 \%$. Berdasarkan mutu warna, bobot jenis, dan indeks bias yang terbaik adalah rasio 1:4 dengan warna kuning, nilai bobot jenis 0,8805, dan nilai indeks bias 1,396. Sedangkan untuk parameter kelarutan dalam alkohol tidak terdapat perbedaan pada setiap perlakuan dimana nilai kelarutan dalam alkohol seluruh perlakuan adalah 1:1.

\section{Saran}

Saran yang dapat diberikan untuk memperbaiki dan mengembangkan penelitian ini diantaranya:

1. Melakukan penelitian dengan mengkaji faktor lain yang dapat mempengaruhi rendemen dan mutu seperti suhu ekstraksi dan teknik pengadukan.

2. Melakukan ekstraksi dengan menggunakan peralatan ekstraksi berpengaduk otomatis.

3. Perlu adanya penelitian menggunakan perbandingan imbangan bunga dengan pelarut diatas 1:4 hingga diperoleh titik optimal untuk menghasilkan minyak melati dengan rendemen dan mutu yang terbaik.

\section{DAFTAR PUSTAKA}

Amiarsi, D., Yulianingsih, dan Sabari S.D. 2006. Pengaruh Jenis dan Perbandingan Pelarut terhadap Hasil Ekstraksi Minyak Atsiri Mawar. Jurnal Hortikultura 16 (4) :356-359.

Guenther, E. 1987. Minyak Atsiri Jilid I. Penerjemah S. Ketaren. Penerbit Universitas Indonesia. Jakarta.

Harborne, J.B. 1996. Metode Fitokimia: Penemuan Cara Modern Menganalisis Tumbuhan. Padmawinata K, penerjemah; Niksolihin S, editor. Bandung: Penerbit ITB. Terjemahan dari : Phytochemical Methods.

Jayanudin, Ayu Z.L., dan Feni N. 2014. Pengaruh Suhu dan Rasio Pelarut Ekstraksi Terhadap Rendemen dan Viskositas Natrium Alginat dari Rumput Laut Cokelat (Sargassum sp.). Jurnal Integrasi Proses Vol 5 No.1 (51-55). Jurusan Teknik Kimia. Universitas Sultan Ageng Tirtayasa. Cilegon.

Ketaren, S. 1985. Pengantar Teknologi Minyak Atsiri. Balai Pustaka. Jakarta.

Lubis, I.H. 1999. Pengaruh Jenis Lemak dan Frekuensi Penggantian Bunga Secara Enfleurasi terhadap Rendemen dan Mutu Minyak Melati (Jasminum sambac). Skripsi. Fakultas Teknologi Pertanian. Institut Pertanian Bogor. Bogor.

Prabawati, S., Endang D.A., Suyanti, dan Dondy. 2002. Perbaikan Cara Ekstraksi untuk Meningkatkan Rendemen dan Mutu Minyak Melati. J.Hort. Vol. 12 No.4 : 270-275.

Rosmayati, S. 1999. Pengaruh Perbandingan Bunga dengan Pelarut Menguap dan Frekuensi Penggunaan Pelarut untuk Ekstraksi terhadap Rendemen dan Mutu Minyak Melati (Jasminum $s p$.$) . Skripsi. Fakultas Teknologi Pertanian.$ Institut Pertanian Bogor. Bogor.

Rubiarto, D. 1993. Mempelajari Pengaruh Ukuran Bahan dan Lama Penyulingan terhadap Rendemen dan Mutu Minyak Kemukus (Piper cubeba Linn.). Bogor: Skripsi Fakultas Teknologi Pertanian Institut Pertanian Bogor.

Rusli, S. 1985. Penelitian dan Pengembangan Minyak Atsiri Indonesia. Edisi Khusus 2. Balai Penelitian Tanaman Rempah dan Obat. Bogor. 